\title{
Visitor Journey Application Development for Omni-Channels
}

\author{
Bakhtiyor ESANOV ${ }^{\mathrm{a}, 1}$ and Ajantha DAHANAYAKE ${ }^{\mathrm{a}}$ \\ ${ }^{a}$ Lappeenranta-Lahti University of Technology LUT
}

\begin{abstract}
The primary purpose of conducting this research is to determine how campus journey application development is progressing. As a result, this research proposes a conceptual model for visitor journey application development. The study included 100 top ranking educational institutes and additionally included Finnish and Estonian universities. 39 virtual campus tour applications and 36 visitor journey applications are benchmarked in total for this study. Provides an example of visitor journey mapping with features, complexities, and best practices that are influential for improving visitor experience during visitor journey application development.
\end{abstract}

Keywords. Omni-channel, visitor experience, visitor journey, touchpoints

\section{Introduction}

The number of smartphone users continue to increase daily. By 2021, 1 in 2 people worldwide is projected to use the smartphone for their daily use [1]. Companies, enterprises, and organizations in retail and marketing are shifting their strategies for reaching out to public from multi-channel to omni-channel strategy. Channel is a medium to reach out to visitors. For example in e-commerce, channels are divided into two types: physical and digital. Physical channels are mail, catalogs, showrooms, and brick and motor stores. Digital channels are websites, email, mobile applications, web applications, social media, e-marketplace, virtual, and mixed reality applications.

Multi-channel is a strategy where channels are heterogeneous, separated, and not integrated. The visitors cannot trigger channel interactions, and the enterprise cannot control channel interaction and integration [2]. Figure 1a presents the visitor's interaction in the multi-channel environment, and channels are not integrated. However, in omnichannel strategy channels are integrated, visitors can trigger channel interaction and have a seamless visitor experience. The enterprise has full control over channel integration and interaction [2].

The omni-channel's primary purpose is to present a single view to the visitor in a consistent manner to supply the visitor's needs. Omni-channels originated as a retail and marketing concept to improve customer visits and their experience. Therefore, in this respect, we consider customer visiting a channel as a visitor and it is slightly different from a user as defined computer science and human computer interaction domain. The challenge of software developers is to provide the visitors that seamless experience so

1 Corresponding Author, Bakhtiyor Esanov, School of Engineering Science, Lappeenranta-Lahti University of Technology LUT, Yliopistonkatu 34, 53850, Lappeenranta, Finland; E-mail: bakhtiyor.esanov@student.lut.fi. 
that they can interact whenever, wherever, and however, they want across all the channels, and with multiple touchpoints integrated. Figure $1 \mathrm{~b}$ presents channel integration in omni-channel strategy.

Understanding visitor's expectations is another aspect for providing a seamless, consistent experience across all channels and touchpoints.
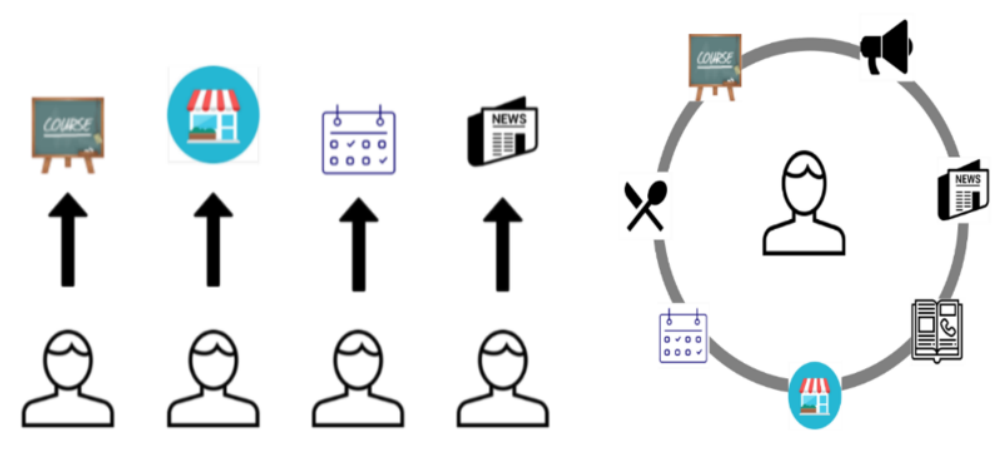

Figure 1.a) multi-channel, b) omni-channel

The recent developments in technology are virtual reality, augmented reality, mixed reality, and the internet of things. These developments bring challenges to visitor journey definitions in retail as well as university and other environments that want to improve the visitor experience of their brand. A visitor journey is similar to visiting a brick and motor store in the virtual space through web application or web site. Many universities have built their visitor journey applications. For example Harvard, Massachusetts Institute of Technology (MIT), Stanford University, and University Jyvaskyla have their visitor journey applications.

Visitor journey applications are very important for brand identity, service improvements, brand experience, giving the right service to the right person, and interaction between brand and customers.

In this research, we investigate visitor journey applications, types of visitor journey applications, overall investigation of how channels are integrated, and features of the visitor journey. This study has a limitation. Mainly, this paper focuses on university visitor journey applications. In the end, we present the functionality and requirements for building visitor journey applications.

There are various types of visitor interactions in visitor journey applications. These users can be students, staff, parents, and other visitors in an education environment. Omni-channel is not a strategy only for retail industry. However, it can be used in various industries to build integrated, seamless visitor experience.

This study aims to investigate various types of visitor journey applications for omnichannel visitor journey application development. We discuss the importance of customized and personalized visitor experience for such application development. In this research, we use benchmarking to identify best practices for the improvement of visitor experience while using mobile applications. We investigate the world's top 100 universities [3] mobile applications(apps), and web apps. Surprisingly most of the universities do not own their visitor journey applications.

The structure of the paper is as follows. The second section presents an overview of the research methods used in this research. The third section lists previous studies about 
campus journey applications. The fourth section of the paper reports the findings of the benchmarking of campus journey applications. The fifth and sixth chapters of the paper introduces the research results from campus journey applications. The sixth chapter summarizes the paper.

\section{Research Approach}

\subsection{Systematic Literature Review}

In order to accomplish research goals, the research must be driven in a theoretical and analytical approach. In the first step of this research work, we address recent papers on visitor journey applications by conducting a systematic literature review [4]. Within the systematic literature review, we have focused on investigating into applications of successful visitor journey applications and visitor's experience cases with the main interest in architectures used, seeking to understand how omni-channel environments can integrate visitor's touchpoints through a full range of functionality integration for optimum visitor engagement and satisfaction.

The literature review helped the identification and classification of omni-channel architectures as the first step, and this study firstly reviews the characteristics of omnichannel environments in visitor journey applications.

Search keywords used for the systematic literature review are omni-channel, customer/visitor journey, user experience, virtual campus, campus journey, touchpoint, journey planning.

The systematic literature review is selected as part of the research approach for this study[4]. Table 1 provides the selected articles for review. After the literature study, we conducted benchmarking of university visitor journey applications to arrive at gathering data for building the research objectives.

Table 1.List of reviewed studies

\begin{tabular}{|l|l|}
\hline Paper Title & Focused Keyword \\
\hline $\begin{array}{l}\text { Omni-Channel Product Distribution Network Design by Using the } \\
\text { Improved Particle Swarm Optimization Algorithm[5] }\end{array}$ & $\begin{array}{l}\text { Omni-channel, user } \\
\text { experience }\end{array}$ \\
\hline Enhanced Visitor Experience Through Campus Virtual Tour[6] & $\begin{array}{l}\text { Virtual campus, } \\
\text { campus journey }\end{array}$ \\
\hline $\begin{array}{l}\text { System Architecture for Virtual Team Campus on Cloud to Support } \\
\text { Internal Quality Assurance of Rajamangala University of } \\
\text { Technology[7] }\end{array}$ & Virtual Campus \\
\hline $\begin{array}{l}\text { User Experience in Mobile Augmented Reality: Emotions, } \\
\text { Challenges, Opportunities and Best Practices[8] }\end{array}$ & User experience \\
\hline $\begin{array}{l}\text { Mapping Learner-Data Journeys: Evolution of a Visual Co-Design } \\
\text { Tool[9] }\end{array}$ & User journey \\
\hline $\begin{array}{l}\text { Learning Multi-touch Conversion Attribution with Dual-attention } \\
\text { Mechanisms for Online Advertising[10] }\end{array}$ & Touchpoint \\
\hline $\begin{array}{l}\text { Key Factors for In-Store Smartphone Use in an Omnichannel } \\
\text { Experience: Millennials vs. Nonmillennials[11] }\end{array}$ & $\begin{array}{l}\text { Omni-channel, user } \\
\text { experience }\end{array}$ \\
\hline $\begin{array}{l}\text { Virtual reality interactive media for universitas sumatera utara - a } \\
\text { campus introduction and simulation[12] }\end{array}$ & $\begin{array}{l}\text { Virtual campus, } \\
\text { campus journey }\end{array}$ \\
\hline
\end{tabular}




\begin{tabular}{|l|l|}
\hline Journey Mapping the User Experience[13] & $\begin{array}{l}\text { User journey, user } \\
\text { experience }\end{array}$ \\
\hline T2*-Personalized Trip Planner[14] & touchpoint \\
\hline The Case for Graph-based Recommendations[15] & User experience \\
\hline $\begin{array}{l}\text { Understanding Mobile Phone Activities via Retrospective Review of } \\
\text { Visualizations of Usage Data[16] }\end{array}$ & User experience \\
\hline Challenges on the Journey to Co-Watching YouTube[17] & $\begin{array}{l}\text { User journey, } \\
\text { journey planning }\end{array}$ \\
\hline $\begin{array}{l}\text { Development Plan for Research on Omni-Channel Shopping to } \\
\text { Purchase Intention[18] }\end{array}$ & Omni-channel \\
\hline $\begin{array}{l}\text { Context-Aware User Modeling Strategies for Journey Plan } \\
\text { Recommendation[19] }\end{array}$ & User journey \\
\hline $\begin{array}{l}\text { VICTour 1.1: Introducing virtual learning environments and } \\
\text { gamification[20] }\end{array}$ & $\begin{array}{l}\text { User journey, virtual } \\
\text { campus }\end{array}$ \\
\hline $\begin{array}{l}\text { An Application of Game Technology to Virtual University Campus } \\
\text { Tour and Interior Navigation[21] }\end{array}$ & Virtual campus \\
\hline Just Browsing? Understanding User Journeys in Online TV[22] & User journey \\
\hline $\begin{array}{l}\text { Mobility Crowdsourcing: Toward Zero-Effort Carpooling on } \\
\text { Individual Smartphone[23] }\end{array}$ & User journey \\
\hline $\begin{array}{l}\text { Customer Experience Modeling: Designing Interactions for Service } \\
\text { Systems[24] }\end{array}$ & User experience \\
\hline $\begin{array}{l}\text { Redefining Touchpoints: An Integrated Approach for Implementing } \\
\text { Omnichannel Service Concepts[25] }\end{array}$ & $\begin{array}{l}\text { Touchpoints, user } \\
\text { experience }\end{array}$ \\
\hline The mobile university: from the library to the campus[26] & Virtual campus \\
\hline Which platform do our users prefer: website or mobile app?[27] & User journey \\
\hline A framework for evaluating university mobile websites.[28] & User experience \\
\hline Customer experience evaluation in the omnichannel environment[29] & $\begin{array}{l}\text { User experience, } \\
\text { omni-channel }\end{array}$ \\
\hline
\end{tabular}

\section{State of visitor journey applications}

\subsection{Omni-Channel}

Omni-channel is the deep integration of all available physical and digital channels into one touchpoint [5] to create a seamless visitor experience across channels. The enterprises such as in retail industry offer visitors a wide range of possibilities to interact with their products. At present such means are: the physical store, catalogs, telephone, web app, and mobile app. Additionally, the visitor can trigger full interaction, and the enterprise controls full integration of all channels [2]. Föhr Janne et al. [29] groups the channels into online, offline, and complex channels. Complex channels are promotions, showroom, and advertisements.

A university visitor journey applications can be identified as a journey through services such as student services, university news services, sports facilities, email service, library services, courses and learning management systems, calendar services, booking room service, restaurants, and cafes and many more. 
Ana Mosquera et al. [11] identifies the key factors influencing visitor's intention to use smartphone devices while visiting the in-store and having an omni-channel experience. Those key factors are performance expectancy, effort expectancy, social influence, facilitating conditions, hedonic motivation, habit, price, and value. Behavior intention is the superset of these factors. Behavior intention, facilitating conditions, and habits directly and positively affects visitor's behavior. The physical store is preferred as the main channel for selling consumer goods or services to customers in retail. With the revolution of mobile technology, customers are ahead of retailers. The customer researches the online to find about the product before visiting the physical store. In the physical store, the customer expects a brand experience.

Some enterprises have already implemented this omni-channel approach successfully. Examples are:

Disney: Once a trip is booked, My Disney Experience tool leads to planning the entire trip, taking care of all details to locate the attractions the visitor wants to see, and the estimated wait time for each of them [30].

Virgin Atlantic: A customer service experience is shared, is a story of personalized user experience with a representative of Virgin Atlantic who reaches across the company's different marketing channels to give the customer personalized service experience [31].

Oasis: is a fashion retailer with a fancy e-commerce site, mobile app, and several brick-and-mortar locations. They fuse those channels to give a visitor a simple and great shopping experience [32].

\subsection{Touchpoint}

Kronqvist et al.[25] distinguishes touchpoints into physical touchpoints, digital touchpoints, and social touchpoints. Physical touchpoints are cards, signs, brochures, service desk, robots, etc. Digital touchpoints are web, mobile, tablets, Augmented/Virtual Reality, chat, artificial intelligence, etc. Social touchpoints are customer service, sales, reception, maintenance, etc. During the visitor journey, the visitor can use different devices, interact with a variety of touchpoints, and can choose a large number of distributed channels, websites, and apps [14].

Stein et al. [33] collected qualitative data obtained from interviews and analyzed thematically to identify elements of customer experience touchpoints. This analysis reveals seven elements of touchpoints: atmospheric, technological, communicative, process, employee-customer interaction, customer-customer interaction, product interaction. Atmospheric elements such as sensory factors, visual effects (paintings, colors), and story layouts are essential in visitor experience. Technological elements have a direct interaction with visitors and these technologies (kiosks, social media, mobile applications, websites etc.,) influence the brand experience. Communicative elements are one-way communication from the retailer to the customer and can be advertisements, informative messages, and promotions. Process elements are actions or steps of customer needs such as navigation, waiting time, and service process.

Orchestration and alignment of these various touchpoints in time and quality form a harmonious experience, and successful alignment result in positive visitor experiences [25]. 


\subsection{Visitor Journey}

Customer or visitor experience is dependent of the visitor journey. We consider the visitor journey as a synonym to the user journey or customer journey. The visitor journey is a virtual tour that a visitor navigates while visiting the virtual-space of the omnichannel application. During a visitor journey, the visitor navigates through touchpoints. These touchpoints are services offered to the visitor by the enterprise. Along the visitor journey, visitors must engage in impression management to consider how their choices might make them appear to others. Emily Sun et al.[17] explores the short-form video co-watching journey. The journey starts with searching for pre-watched content or taking the time to find new content, to negotiating or turn-taking to make a decision, to switching videos less when with another person. The video-sharing platform YouTube merge different user's recommended videos based on common interests and recommend to new users.

Journeys of watching TV Patterns Based on [22], the researchers inspect the journeys in each segment to investigate whether to generalize the patterns of user behavior in groups within each time segment and how patterns change over time.

Visitor journeys have starting and ending points. Visitor journey mapping highlights movement through space, track the time required, visitor's interaction with the brand, and pinch points that users might encounter while performing a task [34]. This mapping is integral to understand customer/visitor experience [35].

\subsection{Virtual Campus}

R F Rahmat et. al. [12] implemented the Unity 3D game engine for creating a virtual campus tour application for Universitas Sumatera Utara. In their research, they present steps of creating a virtual environment and end-user tests of the application. They state all end users agreed that the 3D virtual campus is helpful for new students.

Rizawati et al. [6] present the problem of representing campus, facilities, services to potential students with images and videos. However, potential students cannot participate at the intended on-campus information day time and venue. The virtual campus tour allows the potential students to visualize and explore campus environments virtually and have a significant impact on choosing campus for their studies.

\section{Benchmarking University visitor journey applications}

Camp [36] defines Benchmarking as a process of measuring, finding, comparing products, services with the companies, with the leaders in the same sector of the industry. One of the essential steps of the benchmarking process is searching for the best in set of companies or organizations [37].

After conducting a pilot search, testing, and examining different mobile applications in university mobile application segment, the criteria for comparing the visitor journey applications is identified. Figure 2 presents the steps of the benchmarking process. Different universities are compared according to the selected criteria. The list of 36 benchmarked university visitor journey applications are presented in Table 2. The benchmarking process is conducted between April 2019-July, 2019. Data collection for benchmarking is performed with iPhone 6, iPad 2, Samsung Galaxy J3 and Lenovo Yoga 510 devices. Findings are enumerated below. 


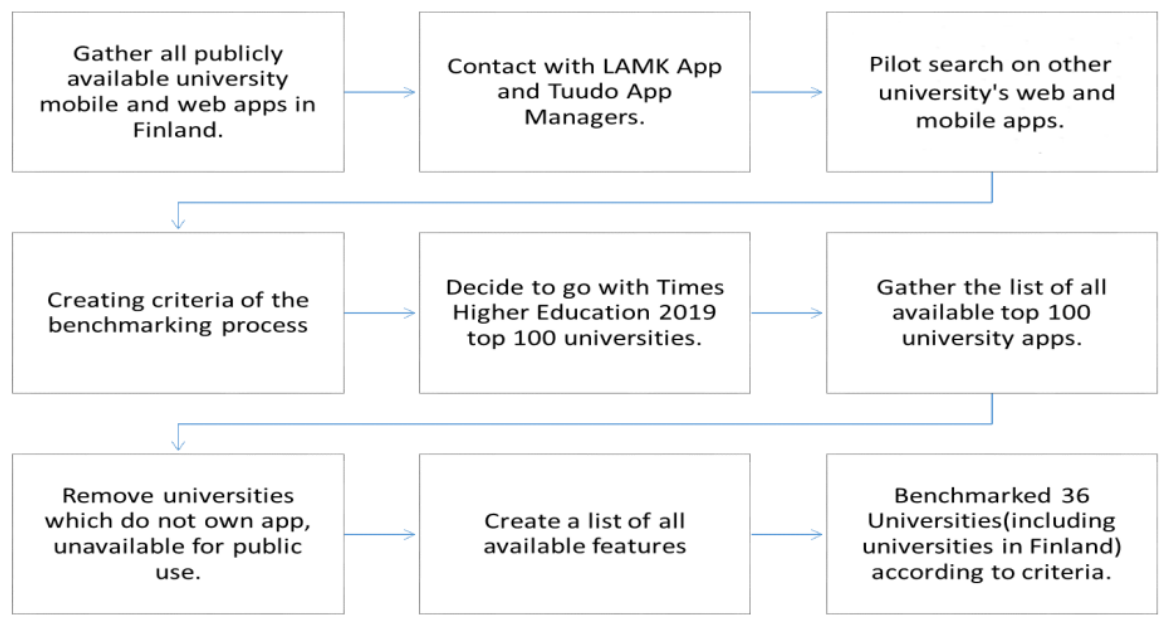

Figure 2. Process of Benchmarking

Table 2.List of Benchmarked Universities

\begin{tabular}{|l|l|l|l|l|l|l|}
\hline University Name & App Name & $\begin{array}{l}\text { Androi } \\
\text { d } \\
\text { Version }\end{array}$ & $\begin{array}{l}\text { IOS } \\
\text { Versi } \\
\text { on }\end{array}$ & $\begin{array}{l}\text { Web App } \\
\text { version }\end{array}$ & $\begin{array}{l}\text { Year of } \\
\text { First } \\
\text { Release }\end{array}$ & Country \\
\hline Stanford University & $\begin{array}{l}\text { Stanford } \\
\text { Mobile }\end{array}$ & Yes & Yes & Yes & 2016 & $\begin{array}{l}\text { United States of } \\
\text { America }\end{array}$ \\
\hline $\begin{array}{l}\text { Massachusetts } \\
\text { Institute } \\
\text { Technology }\end{array}$ & $\begin{array}{l}\text { MIT } \\
\text { Mobile }\end{array}$ & Yes & Yes & Yes & 2011 & $\begin{array}{l}\text { United States of } \\
\text { America }\end{array}$ \\
\hline $\begin{array}{l}\text { California Institute of } \\
\text { Technology }\end{array}$ & $\begin{array}{l}\text { CSR(Caltec } \\
\text { h Student } \\
\text { Resources) }\end{array}$ & Yes & Yes & No & 2018 & $\begin{array}{l}\text { United States of } \\
\text { America }\end{array}$ \\
\hline Harvard University & Harvard & Yes & Yes & Yes & 2012 & $\begin{array}{l}\text { United States of } \\
\text { America }\end{array}$ \\
\hline Princeton University & $\begin{array}{l}\text { Princeton } \\
\text { Mobile }\end{array}$ & Yes & Yes & Yes & 2013 & $\begin{array}{l}\text { United States of } \\
\text { America }\end{array}$ \\
\hline Yale University & Yale & Yes & Yes & No & 2018 & $\begin{array}{l}\text { United States of } \\
\text { America }\end{array}$ \\
\hline $\begin{array}{l}\text { Imperial College } \\
\text { London }\end{array}$ & Imperial & Yes & Yes & Yes & 2011 & Great Britain \\
\hline ETH Zurich & ETH Zurich & Yes & Yes & No & 2012 & Switzerland \\
\hline $\begin{array}{l}\text { University } \\
\text { California, Berkeley }\end{array}$ & Berkeley & Yes & Yes & No & 2018 & $\begin{array}{l}\text { United States of } \\
\text { America }\end{array}$ \\
\hline Duke University & $\begin{array}{l}\text { Dukemobil } \\
\text { e }\end{array}$ & Yes & Yes & Yes & 2011 & $\begin{array}{l}\text { United States of } \\
\text { America }\end{array}$ \\
\hline Cornell University & $\begin{array}{l}\text { Cornell } \\
\text { Connects }\end{array}$ & Yes & Yes & No & 2018 & $\begin{array}{l}\text { United States of } \\
\text { America }\end{array}$ \\
\hline $\begin{array}{l}\text { University of Toronto } \\
\text { U of T } \\
\text { Mobile }\end{array}$ & Yes & Yes & No & 2013 & Canada \\
\hline $\begin{array}{l}\text { Lahti University of } \\
\text { Applied Science }\end{array}$ & $\begin{array}{l}\text { LAMK } \\
\text { APP }\end{array}$ & Yes & Yes & No & 2017 & Finland \\
\hline $\begin{array}{l}\text { École Polytechnique } \\
\text { Fédérale de Lausanne }\end{array}$ & $\begin{array}{l}\text { EPFL } \\
\text { Campus }\end{array}$ & Yes & Yes & No & 2011 & Switzerland \\
\hline Jyvaskyla University & MyJYU & Yes & Yes & Yes & 2019 & Finland \\
\hline
\end{tabular}




\begin{tabular}{|c|c|c|c|c|c|c|}
\hline Tuudo App & Tuudo App & Yes & Yes & No & 2016 & Finland \\
\hline $\begin{array}{l}\text { University College } \\
\text { London(UCL) }\end{array}$ & UCL Go! & Yes & Yes & Yes & 2011 & Great Britain \\
\hline $\begin{array}{l}\text { Technical University } \\
\text { of Munich(TUM } \\
\text { Campus) }\end{array}$ & $\begin{array}{l}\text { TUM } \\
\text { Campus }\end{array}$ & Yes & Yes & No & 2011 & Germany \\
\hline $\begin{array}{ll}\text { The University } & \text { of } \\
\text { North Carolina } & \text { at } \\
\text { Chapel Hill } & \\
\end{array}$ & $\begin{array}{l}\text { CarolinaG } \\
\mathrm{O}\end{array}$ & Yes & Yes & No & 2014 & $\begin{array}{l}\text { United States of } \\
\text { America }\end{array}$ \\
\hline $\begin{array}{lr}\text { University } & \text { of } \\
\text { California, } & \text { Santa } \\
\text { Barbara } & \\
\end{array}$ & $\begin{array}{l}\text { UCSB-UC } \\
\text { Santa } \\
\text { Barbara } \\
\end{array}$ & Yes & Yes & No & 2016 & $\begin{array}{l}\text { United States of } \\
\text { America }\end{array}$ \\
\hline McGill University & McGill & Yes & Yes & No & 2014 & Canada \\
\hline $\begin{array}{l}\text { University of } \\
\text { Pennsylvania(Penn } \\
\text { Mobile) }\end{array}$ & $\begin{array}{l}\text { Penn } \\
\text { Mobile }\end{array}$ & Yes & Yes & No & 2015 & $\begin{array}{l}\text { United States of } \\
\text { America }\end{array}$ \\
\hline $\begin{array}{l}\text { The University of } \\
\text { Texas at Austin } \\
\text { (MyUT Texas) }\end{array}$ & $\begin{array}{l}\text { MyUT } \\
\text { Texas }\end{array}$ & Yes & Yes & No & 2018 & $\begin{array}{l}\text { United States of } \\
\text { America }\end{array}$ \\
\hline $\begin{array}{ll}\text { University } & \text { of } \\
\text { Wisconsin } & \\
\end{array}$ & Wisconsin & Yes & Yes & No & 2011 & $\begin{array}{l}\text { United States of } \\
\text { America }\end{array}$ \\
\hline $\begin{array}{l}\text { The University of } \\
\text { Sydney University }\end{array}$ & Sydney Uni & Yes & Yes & No & 2012 & Australia \\
\hline $\begin{array}{ll}\text { Wageningen } & \\
\text { University } & \& \\
\text { Research } & \\
\end{array}$ & $\begin{array}{l}\text { WUR } \\
\text { W'App }\end{array}$ & Yes & Yes & No & $\begin{array}{l}\text { not } \\
\text { found }\end{array}$ & Netherlands \\
\hline $\begin{array}{ll}\text { University } & \text { of } \\
\text { Amsterdam } & \\
\end{array}$ & My UvA & Yes & Yes & No & 2015 & Netherlands \\
\hline $\begin{array}{l}\text { The University of } \\
\text { Hong Kong }\end{array}$ & $\mathrm{HKU}$ & Yes & Yes & No & 2012 & China \\
\hline New York University & $\begin{array}{l}\text { NYU } \\
\text { mobile }\end{array}$ & Yes & Yes & No & 2012 & $\begin{array}{l}\text { United States of } \\
\text { America }\end{array}$ \\
\hline $\begin{array}{ll}\text { Université } & \text { PSL(Paris } \\
\text { Sciences \& } & \text { Lettres - } \\
\text { PSL } & \text { Research } \\
\text { University) } & \\
\end{array}$ & My.PSL & Yes & Yes & No & 2017 & France \\
\hline $\begin{array}{l}\text { The University of } \\
\text { Melbourne }\end{array}$ & my.unimelb & Yes & Yes & No & 2014 & Austalia \\
\hline $\begin{array}{l}\text { University of British } \\
\text { Columbia }\end{array}$ & $\mathrm{UBC}$ & Yes & Yes & Yes & 2014 & Canada \\
\hline $\begin{array}{lr}\text { The } & \text { Chinese } \\
\text { University of Hong } \\
\text { Kong }\end{array}$ & $\begin{array}{l}\text { CUHK } \\
\text { Mobile }\end{array}$ & Yes & Yes & No & 2012 & Hong Kong \\
\hline $\begin{array}{ll}\text { King's } & \text { College } \\
\text { London } & \\
\end{array}$ & $\begin{array}{l}\text { King's } \\
\text { Mobile }\end{array}$ & Yes & Yes & Yes & 2012 & Great Britain \\
\hline $\begin{array}{l}\text { Nanyang } \\
\text { Technological } \\
\text { University } \\
\end{array}$ & $\begin{array}{l}\text { NTU } \\
\text { Mobile }\end{array}$ & Yes & Yes & No & 2011 & Singapore \\
\hline
\end{tabular}

\subsection{Mobile Apps}

Android is one of the most used mobile operating systems and holds more than $75 \%$ of the mobile devices market share worldwide [38]. Google Play is the largest app store for downloading the applications and installing on supported mobile devices. Google maintains the Google Play Store. Android has a large community of application 
developers and supported by Google. From the benchmarking data, we can clearly state that almost every mobile application has an Android version.

IOS is the second-largest [38] mobile operating system runs on Apple mobile devices such as iPhone, iPad tablets, iPod Touch. IOS applications can be downloaded from the App Store and installed on supported devices. Apple maintains the App Store and supports its developer community. IOS version is the same version of the Android version of the mobile application. During the benchmarking it is discovered, there is a minor platform-specific design difference between Android and IOS in the user interface of the application.

\subsection{Web Applications}

The web application is a compatible web-browser based version of the same mobile application. The web application does not require to install on the user desktop. Web Application runs on all available web browsers such as Safari, Google Chrome, Mozilla Firefox, Microsoft Edge, Yandex. Android and IOS mobile applications run on a specific operating system. However, the web application does not depend on any operating system. Mobile applications can be downloaded from the Google Play Store and App Store and installed on mobile devices.

On the other hand, experiencing a web application is simple, can access by URL address of the web application, and the application contents load to the user's browser. The user of the web application can experience the latest version of the mobile application without any update notice of mobile application. Table 3 shows the list of universities, which have a web application version of their same mobile applications. With the web application, organizations can reach all available audiences, and audiences are free to experiences the brand without devices and operating system dependency.

The visitor starts his/her journey with the mobile application and can continue his/her journey with the web application. With the combining of web and mobile applications, the visitor's experience is seamless, consistent, and integrated.

Table 3. List of Web applications

\begin{tabular}{|l|l|}
\hline Universities & Web Application URL \\
\hline Stanford University & https://m.stanford.edu \\
\hline Massachusetts Institute of Technology & https://mobi.mit.edu/ \\
\hline Harvard University & https://m.harvard.edu/ \\
\hline Princeton University & https://m.princeton.edu \\
\hline Imperial College London & https://mobile.imperial.ac.uk/ \\
\hline Duke University & https://mobile.duke.edu/ \\
\hline Jyvaskyla University & https://myjyu.jyu.fi/ \\
\hline University College London(UCL) & https://ucl.ombiel.co.uk/ \\
\hline University of British Columbia & https://m.ubc.ca \\
\hline King's College London & https://kingsmobile.kcl.ac.uk \\
\hline
\end{tabular}


From the benchmarking data in Table 2, we discover that visitor journey applications appeared from the beginning of 2011. Year of the first release information is based on Android Version. The First-time release data is available only for the users of the Android version. App Store does not show details about the first release of the IOS version of mobile applications.

\subsection{Features}

Universities may have several campuses in different countries or cities. Furthermore, campuses located in different corners of cities. Every campus has its facilities and services. Campus selection automatically updates the touchpoints data source with selected campus's services and channels. The visitor journey application automatically updates its data with campus services. New York University (NYU Mobile) and Technical University of Munich (TUM Campus) have campus selection feature.

Visitor mode is an essential feature for visitor journey applications. In visitor mode, visitors can use the application without a login to the application. The visitor mode has limited features. In visitor mode, visitors can not $\log$ in to the system. During the benchmarking process, we removed applications from the list which do not have the visitor mode.

Table 4 shows the list of most user touchpoints by universities, which also include the visitor mode. Some touchpoints require authorization for accessing the system, and these touchpoints are designed for the specific user types. These specific users are students and staff.

The persona can be a student, staff, and authorized campus visitors. With a change persona feature, the experience of the visitor journey is personalized and customized. There are no restrictions for authorized users while using the application. Furthermore, touchpoints such as internal chat and messaging, calendar, personalized schedules, booking room, library, announcements, health services, study space availability, student identification card, jobs, finance, laundry info, parking are fully available for authorized users.

The customized navigation feature provides a more personalized visitor experience of the brand. Customized navigation helps to minimize and organize the touchpoints. The visitor can personalize the application according to his/her specifications and preferences. A visitor can create a list of favorite touchpoints and list appears at the top of the navigation menu and navigational home screen. The application gives the option to add new touchpoints to the list, changes, and adjusts the position of touchpoint to top, bottom, and removes from the list. This feature helps to reach touchpoints quicker.

Following Universities mobile applications have Customized Navigation Feature: Massachusetts Institute of Technology(MIT Mobile), University of California Berkeley(Berkeley), University of Toronto(U of Mobile), École Polytechnique Fédérale de Lausanne(EPFL Campus), University of Pennsylvania(Penn Mobile), University of Sydney University(Sydney Uni), Nanyang Technological University(NTU Mobile). 


\subsection{Customizing the Features}

For customizing the selected touchpoints, the University of Pennsylvania (Penn Mobile), EPFL, ETH Zurich, and Technical University of Munich(TUM Campus) have included these features.

Features may have an extensive range of services and channels. In the visitor journey application context, some features have many services. For example, news. University has a wide range of channels to provide news.

This feature helps to optimize the visitor experience. Moreover, provide a more specific part of the touchpoint. With customizing this feature, the user's experience will be more personalized. Table 4 below provides the most common features related to tuchpoints in visitor journey applications.

Table 4.List of most used Features related to Touchpoints

\begin{tabular}{|c|c|c|c|}
\hline Feature Name & Description & $\begin{array}{l}\text { Visitor } \\
\text { Mode }\end{array}$ & Staff/Student \\
\hline Directory & $\begin{array}{l}\text { Get the contact information for University students, } \\
\text { faculty, and staff, as well as for departments, offices, arts, } \\
\text { athletic venues, libraries, and services. }\end{array}$ & Yes & Yes \\
\hline Map & $\begin{array}{l}\text { Navigate the campus by searching for buildings, } \\
\text { departments, libraries, athletic facilities, dormitories, and } \\
\text { offices. Zoom in, zoom out or scroll in any direction. } \\
\text { Locations include details such as images, website links, } \\
\text { and phone numbers. }\end{array}$ & Yes & Yes \\
\hline Places & $\begin{array}{l}\text { Look up places around campus and the services they } \\
\text { provide. Get detailed information such as open hours, } \\
\text { whether space is reserved, contact information, and } \\
\text { payment types accepted. Examples of places include } \\
\text { residential colleges, the digital print center, and } \\
\text { recreation facilities. }\end{array}$ & Yes & Yes \\
\hline Dining/Restaurants & $\begin{array}{l}\text { Choose where and what user would like to eat. Look up } \\
\text { both residential and retail dining locations and check } \\
\text { open hours, menus, and nutrition information. Integrated } \\
\text { with dining services }\end{array}$ & Yes & Yes \\
\hline Transit/Transportation & $\begin{array}{l}\text { Access transportation routes, schedules, and locations in } \\
\text { real-time. Integrated with the local transportation system. } \\
\text { Read news and see transportation contact information. } \\
\text { Check/load the balance from the transportation system }\end{array}$ & Yes & Yes \\
\hline Events & $\begin{array}{l}\text { Browse the public and student event listings by day and } \\
\text { category. Find the event locations on the campus map. } \\
\text { Access the academic calendar for important dates and } \\
\text { deadlines. }\end{array}$ & Yes & Yes \\
\hline News & $\begin{array}{l}\text { Keep up to date with and share the latest University news } \\
\text { and announcements. }\end{array}$ & Yes & Yes \\
\hline Accommodation & $\begin{array}{l}\text { Integrated with university dormitories website, } \\
\text { Student/User can make book/reservation for Washing } \\
\text { Machine/Dryer/Sauna }\end{array}$ & $\begin{array}{l}\text { Partly } \\
\text { Yes }\end{array}$ & Yes \\
\hline Sports & $\begin{array}{l}\text { Check SportsHall timetables, and news. Book a sports } \\
\text { hall for indoor games. Users can create sports events with } \\
\text { friends. Integrated with sports facilities services }\end{array}$ & Yes & Yes \\
\hline Report & $\begin{array}{l}\text { Submit fault reports concerning campus facilities, } \\
\text { outdoor and indoor areas, report a defect in class, outdoor } \\
\text { and indoor places. }\end{array}$ & Yes & Yes \\
\hline Courses & $\begin{array}{l}\text { Search or browse the course schedule to find descriptions, } \\
\text { meeting days and times, locations, instructors, and class } \\
\text { size. Link to instructor contact information and check } \\
\text { locations on the campus map. }\end{array}$ & $\begin{array}{l}\text { Partly } \\
\text { Yes }\end{array}$ & Yes \\
\hline Library & $\begin{array}{l}\text { Connect to the university library services to search the } \\
\text { catalog, see hours for each library, and send a text } \\
\text { message or check loan status, prolong the book, order } \\
\text { library card }\end{array}$ & No & Yes \\
\hline
\end{tabular}




\begin{tabular}{|c|c|c|c|}
\hline Emergency & $\begin{array}{l}\text { Get quick access to telephone numbers of emergency } \\
\text { services in case of emergency in the university campus }\end{array}$ & Yes & Yes \\
\hline Social & $\begin{array}{l}\text { University social media pages, groups, accounts, and } \\
\text { profiles. Follow University's social media postings on } \\
\text { happenings around campus and breaking news. }\end{array}$ & Yes & Yes \\
\hline Announcements & $\begin{array}{l}\text { Student/Staff can share updates about the important } \\
\text { events, conferences. }\end{array}$ & No & Yes \\
\hline Video/Multimedia & $\begin{array}{l}\text { See a wide variety of videos about the university, made } \\
\text { by students, staff, and faculty, and featuring faculty } \\
\text { members, researchers, student life, and campus beauty. }\end{array}$ & Yes & Yes \\
\hline $\begin{array}{l}\text { Customize } \\
\text { menu/navigation }\end{array}$ & $\begin{array}{l}\text { User can select his/her favorite features, and selected } \\
\text { features appear on the navigation }\end{array}$ & Yes & Yes \\
\hline Settings & User can choose the size of fonts, language settings & Yes & Yes \\
\hline Parking & $\begin{array}{l}\text { Campus Parking places and information, free parking } \\
\text { areas. }\end{array}$ & Yes & Yes \\
\hline Log in $/ \log$ out & $\begin{array}{l}\text { User logins to his/her account, personalized } \\
\text { schedules/contents, notifications, messages }\end{array}$ & No & Yes \\
\hline Chat & Internal chat, group conversations. & No & Yes \\
\hline Marketplace & $\begin{array}{l}\text { Sell, lend and rent things, buy printer quota, buy } \\
\text { university t-shirts/shorts/caps/mugs }\end{array}$ & Yes & Yes \\
\hline Health Service & $\begin{array}{l}\text { Health Service places/Phone number and contact } \\
\text { information }\end{array}$ & No & Yes \\
\hline $\begin{array}{ll}\text { Study } & \text { Space } \\
\text { Availability } & \\
\end{array}$ & $\begin{array}{l}\text { User can check available study/meeting space and can } \\
\text { book it, }\end{array}$ & No & Yes \\
\hline $\begin{array}{l}\text { Student Identification } \\
\text { card }\end{array}$ & Virtual student card verified identification of student. & No & Yes \\
\hline Campus News & Read the latest news from several university news sources & Yes & Yes \\
\hline Laundry Info & $\begin{array}{l}\text { Check availability of washers and dryers located in } \\
\text { campus facilities }\end{array}$ & No & Yes \\
\hline Jobs(Find Jobs) & $\begin{array}{l}\text { See the latest open positions from the University } \\
\text { employment system. }\end{array}$ & No & Yes \\
\hline Finance & Reminds/Shows the student's tuition fee & No & Yes \\
\hline
\end{tabular}

\section{Virtual Campus Tour and Touchpoint Services}

After completing the visitor journey application benchmarking, research continued with top-ranking 60 universities [3] and also included some universities from Finland and Estonia, which have virtual campus tour applications. From the process of benchmarking, 39 virtual campus tour applications are selected. Table 5 shows the list of virtual campus tour applications.

The virtual campus tour application's primary purpose is to promote key areas of both indoor and outdoor campus and attract the attention of prospective students, campus visitors, and prospective student's parents. Users of this application explore the campus facilities, services, locations from their supported devices.

The virtual experience of the campus is priceless. These kinds of applications are good for promoting university services in a good way.

Virtual tour applications increase the physical visits $27 \%$, interactive web content engagement by $38 \%$, and have resulted in $18 \%$ increase in inquires [39].

Map, Menu, Navigation, Photos, Panorama, Video, 360-degree video, voice-guide, Google map, interactive human guide, web app, mobile app, VR device are the supported features selected for comparison criteria. We consider these features are essential and core for building virtual campus tour applications. 
Table 5. List of virtual campus tour applications and selection criteria

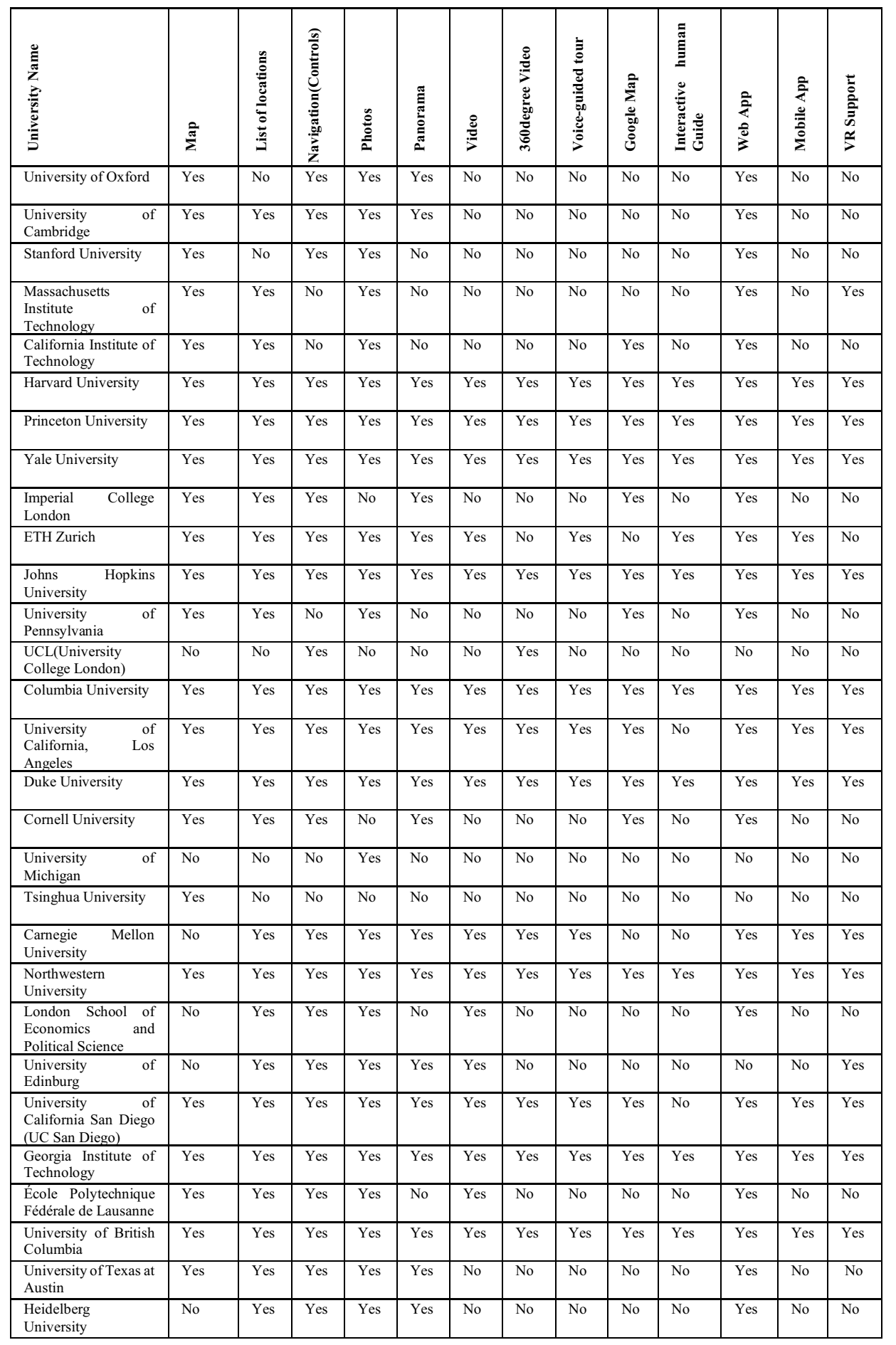




\begin{tabular}{|l|l|l|l|l|l|l|l|l|l|l|l|l|l|}
\hline KU Leuven & No & Yes & Yes & Yes & No & No & No & Yes & No & No & No & No & No \\
\hline $\begin{array}{l}\text { Australian National } \\
\text { University }\end{array}$ & No & Yes & Yes & Yes & Yes & Yes & Yes & No & No & No & Yes & No & No \\
\hline $\begin{array}{l}\text { University of Illinois } \\
\text { at } \\
\text { Champaign }\end{array}$ No & No & Yes & Yes & No & No & No & No & No & No & No & No & No \\
\hline $\begin{array}{l}\text { University of } \\
\text { California, Santa } \\
\text { Barbara }\end{array}$ & Yes & Yes & Yes & Yes & Yes & No & No & Yes & Yes & Yes & Yes & Yes & Yes \\
\hline $\begin{array}{l}\text { Brown University } \\
\text { University of North } \\
\text { Carolina at Chapel } \\
\text { Hill }\end{array}$ & Yes & Yes & Yes & Yes & Yes & Yes & Yes & Yes & Yes & Yes & Yes & Yes & Yes \\
\hline $\begin{array}{l}\text { University } \\
\text { California, Davis of }\end{array}$ & Yes & Yes & Yes & Yes & Yes & No & No & Yes & Yes & Yes & Yes & Yes & Yes \\
\hline $\begin{array}{l}\text { University of Sydney } \\
\text { No }\end{array}$ & Yes & Yes & Yes & Yes & Yes & Yes & Yes & No & No & Yes & Yes & Yes \\
\hline $\begin{array}{l}\text { Tallinn University of } \\
\text { Technology }\end{array}$ & Yes & Yes & Yes & Yes & Yes & Yes & Yes & Yes & Yes & No & Yes & No & Yes \\
\hline $\begin{array}{l}\text { Lahti University of } \\
\text { Applied Science }\end{array}$ & Yes & Yes & Yes & Yes & Yes & No & No & No & No & No & Yes & No & No \\
\hline
\end{tabular}

\section{Conceptualization}

From the findings of benchmarking during the research, the following conceptual model for the visitor journey application is proposed. Figure 3 shows the conceptual model for the visitor journey application. The rationale behind the construction of the conceptual model is as follows: The connection between channels and services is twodirectional. Data flow between channels and touchpoints also two-directional. The visitor journey starts with interacting with touchpoints. Each journey of visitor is recorded to the system during the data collecting process. Understanding the visitor helps to identify how, from where, and which touchpoints visitor interacts with the brand. The software analyzes the collected data from the visitor journey with models, scales, and techniques. The software creates visitor journey mapping. In each visitor journey, the visitor experiences a personalized visitor journey, and the visitor continues the journey from where he/she left each time revisits the application. The process of creating a visitor journey is iterative.

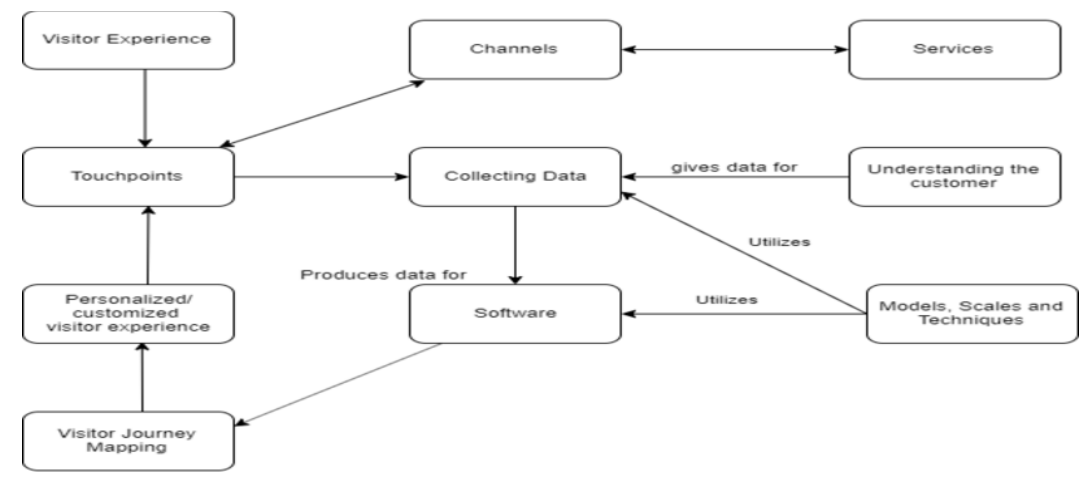

Figure 3.Conceptual model for Visitor Journey Application 
Figure 4 presents the visitor journey process created from the conceptual model for the visitor journey application. A visitor interacts with touchpoints, and each interaction is recorded to the system and creates a list of visitor journeys. The system creates a visitor journey map from the list of visitor journeys and provides a personalized visitor experience. The personalized visitor experience depends on the number of journeys. As the number of journeys increases, personalized visitor experience optimizes, the interaction of the visitor improves.

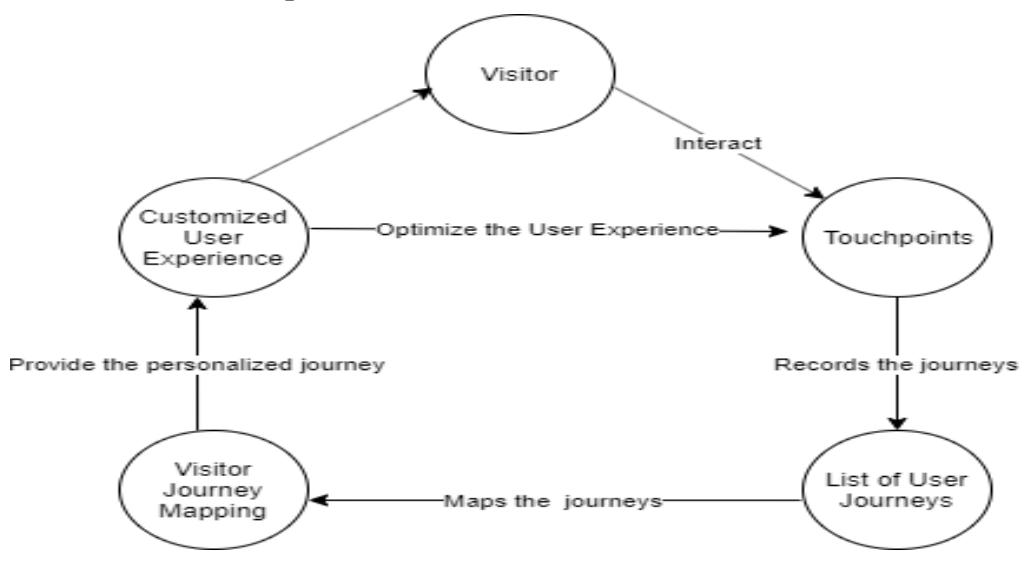

Figure 4.Visitor Journey Application process

\section{Visitor journeys and touchpoints mapping}

Table 6 presents the visitor journey across the touchpoints. A visitor journey starts from any touchpoint and ends in any touchpoint. In Table 6 visitor journey starts from touchpoint (T1) 1 and ends in touchpoint $\mathrm{T}$. $\mathrm{T} 1=>\mathrm{T} 2=>\mathrm{T} 5=>\mathrm{T} 3 \Rightarrow \mathrm{T} 10=>\mathrm{T} 11 \Rightarrow \mathrm{T} 8=>\mathrm{T} 3$ here the simple visitor journey of figure 4.

Table 6:User journey across the touchpoints

\begin{tabular}{|c|c|c|c|c|c|c|c|c|}
\hline & point & $2^{\text {nd }}$ & $3^{\text {rd }}$ & $4^{\text {th }}$ & $5^{\text {th }}$ & $6^{\text {th }}$ & $8^{\text {th }}$ & $9^{\text {th }}$ \\
\hline \multirow{11}{*}{ 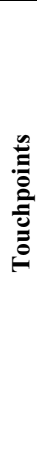 } & $\mathrm{T} 1$ & $\mathrm{~T} 2$ & T1 & T1 & T1 & T1 & T1 & $\mathrm{T} 1$ \\
\hline & $\mathrm{T} 2$ & T3 & T3 & $\mathrm{T} 2$ & $\mathrm{~T} 2$ & $\mathrm{~T} 2$ & $\mathrm{~T} 2$ & $\mathrm{~T} 2$ \\
\hline & T3 & T4 & $\mathrm{T} 4$ & T3 & T3 & T3 & T3 & T3 \\
\hline & $\mathrm{T} 4$ & T5 & T5 & $\mathrm{T} 4$ & $\mathrm{~T} 4$ & $\mathrm{~T} 4$ & $\mathrm{~T} 4$ & $\mathrm{~T} 4$ \\
\hline & T5 & T6 & T6 & T6 & T5 & T5 & T5 & T5 \\
\hline & T6 & $\mathrm{T} 7$ & $\mathrm{~T} 7$ & $\mathrm{~T} 7$ & T6 & T6 & T6 & T6 \\
\hline & $\mathrm{T} 7$ & $\mathrm{~T} 8$ & T8 & T8 & $\mathrm{T} 7$ & $\mathrm{~T} 7$ & $\mathrm{~T} 7$ & $\mathrm{~T} 7$ \\
\hline & T8 & T9 & T9 & T9 & T8 & T8 & $\mathrm{T} 8$ & T9 \\
\hline & T9 & $\mathrm{T} 10$ & $\mathrm{~T} 10$ & $\mathrm{~T} 10$ & T9 & T9 & T9 & $\mathrm{T} 10$ \\
\hline & $\mathrm{T} 10$ & T11 & T11 & $\mathrm{T} 11$ & T10 & $\mathrm{T} 11$ & $\mathrm{~T} 10$ & $\mathrm{~T} 11$ \\
\hline & T11 & & & & & & & \\
\hline
\end{tabular}




\begin{tabular}{|l|l|}
\hline Journeys & Route of Journeys \\
\hline Journey 1 & $\mathrm{~T} 1=>\mathrm{T} 2=>\mathrm{T} 5=>\mathrm{T} 3=>\mathrm{T} 10=>\mathrm{T} 11=>\mathrm{T} 8=>\mathrm{T} 3$ \\
\hline Journey 2 & $\mathrm{~T} 2=>\mathrm{T} 7=>\mathrm{T} 5=>\mathrm{T} 3=>\mathrm{T} 2=>\mathrm{T} 11=>\mathrm{T} 8=>\mathrm{T} 5$ \\
\hline Journey 3 & $\mathrm{~T} 3=>\mathrm{T} 10=>\mathrm{T} 11=>\mathrm{T} 8=>\mathrm{T} 3$ \\
\hline Journey $\mathrm{n} .$. & $\ldots \ldots \ldots . \mathrm{n}$ \\
\hline
\end{tabular}

Table 7: Number of nodes

\begin{tabular}{|l|l|l|l|}
\hline Journey 1 & Journey 2 & Journey 3 & Journey $\mathrm{n} .$. \\
\hline $\mathrm{T} 3=2$ & $\mathrm{~T} 3=3$ & $\mathrm{~T} 3=5$ & $\ldots \mathrm{n}$ \\
\hline $\mathrm{T} 1=1$ & $\mathrm{~T} 5=3$ & $\mathrm{~T} 5=3$ & $\ldots \mathrm{n}$ \\
\hline $\mathrm{T} 2=1$ & $\mathrm{~T} 2=3$ & $\mathrm{~T} 2=3$ & $\ldots \mathrm{n}$ \\
\hline $\mathrm{T} 5=1$ & $\mathrm{~T} 11=2$ & $\mathrm{~T} 8=3$ & $\ldots \mathrm{n}$ \\
\hline $\mathrm{T} 8=1$ & $\mathrm{~T} 8=2$ & $\mathrm{~T} 11=2$ & $\ldots \mathrm{n}$ \\
\hline $\mathrm{T} 10=1$ & $\mathrm{~T} 10=1$ & $\mathrm{~T} 10=2$ & $\ldots \mathrm{n}$ \\
\hline $\mathrm{T} 11=1$ & $\mathrm{~T} 1=1$ & $\mathrm{~T} 1=1$ & $\ldots \mathrm{n}$ \\
\hline & $\mathrm{T} 7=1$ & $\mathrm{~T} 7=1$ & \\
\hline
\end{tabular}

A significant number of visitor journeys help to build visitor journey maps. With machine learning algorithms, it is possible to detect the most used touchpoints; most used combinations of touchpoints, and the duration of the visitor journey. With this information, the user/visitor will have a personalized experience. Analytics can be involved to record each step of the visitor while experiencing the brand. End of the current journey analytic tools draw the visitor's journey network. With the help of the software, new personalized visitor experience will be created dynamically. The visitor can continue the journey where he/she left in the last session. End of each journey analytic tools merge the new visitor journey map with the old one. Here the number of nodes between the touchpoints are important.

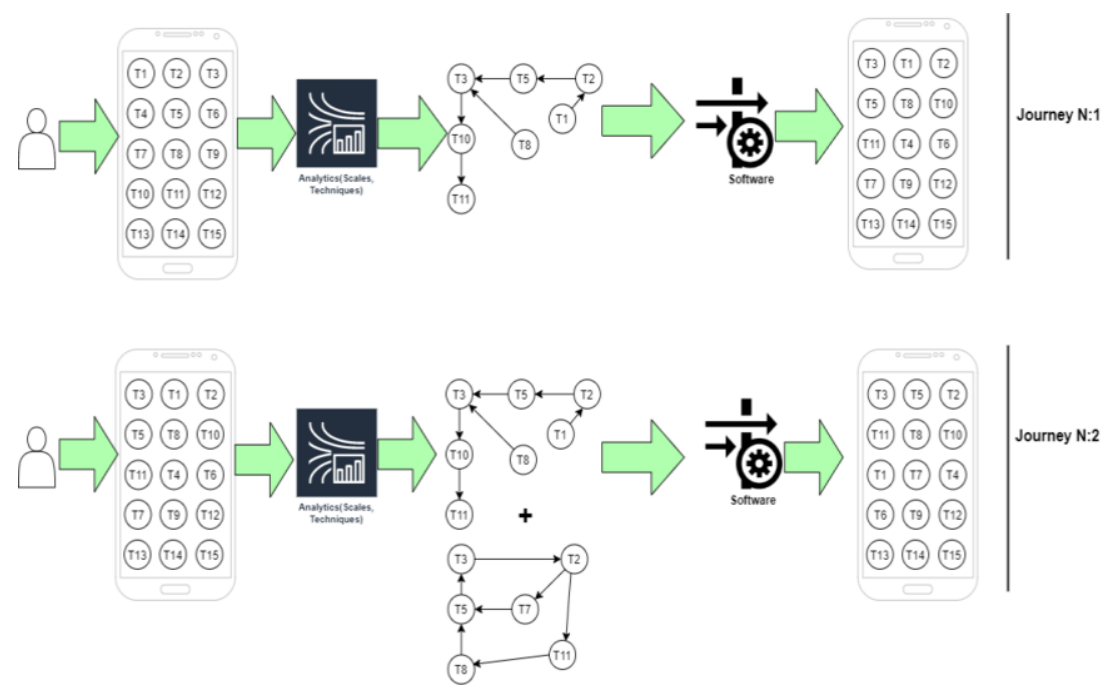

Figure 5: Simulation of the visitor journey mapping 
The high number of nodes will be shown first. In Table 7 the number of nodes connected to the touchpoints are given and calculated. Figure 5 illustrates an example of the above mentioned visitor journey and touchpoints mapping.

\section{Concluding remarks}

The primary purpose of conducting this research is to determine how campus journey application development is progressing. Campus virtual tour applications mostly run on a web browser, and almost every benchmarked visitor journey application of this research have a web app. Campus visitor journey applications mostly run on mobile devices and few of them have web application versions. Some universities, for example, Sydney University, combines virtual campus tour and visitor journey application in one application. From the research findings, we recommend combining the virtual tour with campus journey applications. This task may be challenging. However, there is the advantage of it in allocating resources. Further, this research provided insight into visitor journey application development, how they are used in the present, the features that are necessary for introducing seamless visitor journey mapping, and involving touchpoints of visitor journey applications for improving the customer/visitor experience of omni channels.

\section{References}

[1] "Number of smartphone users worldwide 2014-2020." [Online]. Available: https:/www.statista.com/statistics/330695/number-of-smartphone-users-worldwide/. [Accessed: 01-Nov-2019].

[2] N. Beck and D. Rygl, "Categorization of multiple channel retailing in Multi-, Cross- , and Omni Channel Retailing for retailers and retailing,” J. Retail. Consum. Serv., vol. 27, pp. 170-178, 2015.

[3] "World University Rankings." [Online]. Available: https://www.timeshighereducation.com/worlduniversity-rankings/2019/world-ranking\#!/page/0/length/25/sort_by/rank/sort_order/asc/cols/stats. [Accessed: 01-Nov-2019].

[4] B. Kitchenham, O. P. Brereton, D. Budgen, M. Turner, J. Bailey, and S. Linkman, "Systematic literature reviews in software engineering - A systematic literature review," Inf. Softw. Technol., vol. 51, no. 1, pp. 7-15, 2009.

[5] S. Zhang, H. Zhu, X. Li, and Y. Wang, "Omni-Channel Product Distribution Network Design by Using the Improved Particle Swarm Optimization Algorithm,” vol. 2019, 2019.

[6] M. R. B. P. Rizawati Binti Rohizan, Daniel Mago Vistro, "Enhanced Visitor Experience Through Campus Virtual Tour,” J. Phys. Conf. Ser., vol. 1228, 2019.

[7] V. Kankaew and P. Wannapiroon, "System Architecture for Virtual Team Campus on Cloud to Support Internal Quality Assurance of Rajamangala University of Technology,” vol. 15, no. 7, pp. 99-110, 2019.

[8] T. H. L. Amir Dirin, "User Experience in Mobile Augmented Reality: Emotions, Challenges, Opportunities and Best Practices," Computers, vol. 7, 2018.

[9] C. G. Prieto-alvarez, R. Martinez-maldonado, and S. B. Shum, "Mapping Learner-Data Journeys : Evolution of a Visual Co-Design Tool," Proc. 30th Aust. Conf. Comput. Interact., pp. 205-214, 2018.

[10] Kan Ren, Yuchen Fang, Weinan Zhang, Shuhao Liu, Jiajun Li, Ya Zhang, Yong Yu, Jun Wang, "Learning Multi-touch Conversion Attribution with Dual-attention Mechanisms for Online Advertising," Proc. 27th ACM Int. Conf. Inf. Knowl. Manag., pp. 1433-1442, 2018.

[11] A. Mosquera, E. Juaneda-ayensa, C. Olarte-pascual, and J. Pelegrín-borondo, "Key Factors for InStore Smartphone Use in an Omnichannel Experience : Millennials vs . Nonmillennials," Complexity, vol. Volume 201, 2018.

[12] R F Rahmat, Anthonius, M A Muchtar, A Hizriadi and M F Syahputra, "Virtual reality interactive media for universitas sumatera utara - a campus introduction and simulation," J. Phys. Conf. Ser., 
vol. $978,2018$.

[13] S. Sue, G. Kim, and A. Adrienne, "Journey Mapping the User Experience,” C\&RL, vol. 78, pp. 459$471,2017$.

[14] Joao C.Ferreira, Ana Lucia Martins, Jorge Vieira da Silva, João Almeida, "T2 * - Personalized Trip Planner," Adv. Intell. Syst. Comput., vol. 615, pp. 167-175, 2018.

[15] Iulia Popescu, Kurt Portelli, Christos Anagnostopoulos, Nikos Ntarmos, "The Case for Graph-Based Recommendations," 2017 IEEE Int. Conf. Big Data (Big Data), pp. 4819-4821, 2017.

[16] Y. Bhavnani, K. Rodden, L. C. Guarnotta, M. T. Lynn, S. Chizari, and Laura Granka, "Understanding Mobile Phone Activities via Retrospective Review of Visualizations of Usage Data," MobileHCI '17 Proc. 19th Int. Conf. Human-Computer Interact. with Mob. Devices Serv., 2017.

[17] E. Sun, R. De Oliveira, and J. Lewandowski, "Challenges on the Journey to Co-Watching YouTube," CSCW 2017, pp. 783-793, 2017.

[18] D. B. Viany Utami Tjhin, Bahtiar S.Abbas, Raymond Kosala, "Development Plan for Research on Omni-Channel Shopping to Purchase Intention,” 2016 Int. Conf. Inf. Manag. Technol., pp. 229-234, 2016.

[19] V. Codina, J. Mena, and Luis Oliva, "Context-Aware User Modeling Strategies for Journey Plan Recommendation," UMAP 2015 User Model. Adapt. Pers., pp. 68-79, 2015.

[20] C. L.Maines, S. Tang, and David Llewellyn-Jones, "VICTour 1 . 1 : Introducing virtual learning environments and gamification,” 2015 Int. Conf. Dev. E-Systems Eng., pp. 159-164, 2015.

[21] C. Maines and S. Tang, "An Application of Game Technology to Virtual University Campus Touring and Interior Navigation,” 2015 Int. Conf. Dev. E-Systems Eng., pp. 341-346, 2015.

[22] Y. Elkhatib, R. Killick, M. Mu, and N. Race, "Just Browsing ? Understanding User Journeys in Online TV Initial observations,” pp. 965-968.

[23] N. Liu, Y. Feng, F. Wang, B. Liu, and J. Tang, "Mobility Crowdsourcing: Toward Zero-Effort Carpooling on Individual Smartphone," vol. 2013, 2013.

[24] J. Teixeira, L. Patrício, N. J. Nunes, and L. Nóbrega, "Customer Experience Modeling : Designing Interactions for Service Systems,” pp. 136-143, 2011.

[25] J. Kronqvist and T. Leinonen, "Redefining Touchpoints : An Integrated Approach for Implementing Omnichannel Service Concepts," in Springer, Cham, pp. 279-288.

[26] S. Wilson and G. Mccarthy, "The mobile university : from the library to the campus," Ref. Serv. Rev., vol. 38 No. 2, pp. 214-232, 2010.

[27] S. Han and R. Wong, "Which platform do our users prefer : website or mobile app ?," vol. 40, no. 1, pp. 103-115, 2012.

[28] H. S. Al-khalifa, “A framework for evaluating university mobile websites,” Emerald Gr. Publ. Ltd., vol. 38 No. 2, pp. 166-185, 2012.

[29] Föhr Jann, Hietanen Hannes, Khvatov Artem, Lepistö Toni, Liukka, Niko, Dahanayake Ajantha, "Customer experience evaluation in the omnichannel environment," in Frontiers in Artificial Intelligence and Applications, 2017, vol. 301, 2018, pp. 21-34.

[30] "Disney Parks." [Online]. Available: https://disneyparks.disney.go.com/. [Accessed: 27-Nov-2018].

[31] Fransgaard, "Getting an omni-channel customer service experience as a Virgin advocate." [Online]. Available: http://fransgaard.com/getting-an-omni-channel-customer-service-as-a-virgin-advocate/. [Accessed: 28-Nov-2019].

[32] "Oasis." [Online]. Available: https://www.oasis-stores.fi/. [Accessed: 26-Nov-2019].

[33] A. Stein and B. Ramaseshan, "Towards the identification of customer experience touch point elements," J. Retail. Consum. Serv., vol. 30, pp. 8-19, 2016.

[34] J. J. Marquez, A. Downey, and R. Clement, "Walking a Mile in the User' s Shoes : Customer Journey Mapping as a Method to Understanding User Experience," Internet Ref. Serv. Q., vol. 20, no. 3-4, pp. 135-150, 2015.

[35] G. C. R. Mark S Rosenbaum, Mauricio Losada Otalora, "How to create a realistic customer journey map," Bus. Horiz., vol. 60, no. 1, pp. 143-150, 2017.

[36] R. C. Camp, "Business Process Benchmarking: Finding and Implementing Best Practices," Milwaukee ASQC Qual. Press, 1995.

[37] H. L. Richardson, "Improve Quality Through Benchmarking," Transp. Distrib., no. Oct 1992; 33, pp. 32-37, 1992.

[38] "Mobile Operating System Market Share Worldwide," StatCounter, 2019. [Online]. Available: https://gs.statcounter.com/os-market-share/mobile/worldwide. [Accessed: 09-Dec-2019].

[39] "YouVisit," 2020. [Online]. Available: https://www.youvisit.com/. [Accessed: 10-Jan-2020]. 